\title{
Fault activity and lateral extrusion inferred from velocity field revealed by GPS measurements in the Pingtung area of southwestern Taiwan
}

\author{
Jyr-Ching $\mathrm{Hu}^{\mathrm{a}, *}$, Chin-Shyong Hou ${ }^{\mathrm{b}}$, Li-Chung Shen ${ }^{\mathrm{a}}$, Yu-Chang Chan ${ }^{\mathrm{c}}$, \\ Rou-Fei Chen ${ }^{\mathrm{d}}$, Chung Huang ${ }^{\mathrm{a}}$, Ruey-Juin Rau ${ }^{\mathrm{e}}$, Kate Hui-Hsuan Chen ${ }^{\mathrm{e}}$, \\ Chii-Wen Lin ${ }^{\mathrm{b}}$, Mong-Han Huang ${ }^{\mathrm{a}}$, Pei-Fen Nien ${ }^{\mathrm{a}}$ \\ ${ }^{a}$ Department of Geosciences, National Taiwan University, No. 1, Sec. 4, Roosevelt Road, Taipei 106, Taiwan \\ ${ }^{\mathrm{b}}$ Central Geological Survey, MOEA, PO Box 968, Taipei, Taiwan \\ ${ }^{\mathrm{c}}$ Institute of Earth Sciences, Academia Sinica, Nankang, Taiwan \\ ${ }^{\mathrm{d}}$ Observatoire Océanologique de Villefranche-sur-Mer, Université P.\&M. Curie, Villefranche-sur-Mer, France \\ ${ }^{\mathrm{e}}$ Department of Earth Sciences, National Cheng Kung University, Tainan, Taiwan
}

Received 5 May 2004; received in revised form 18 February 2005; accepted 27 July 2006

\begin{abstract}
Four campaigns of dense GPS measurements have been conducted since 1995 to investigate crustal deformation patterns in SW Taiwan. The station velocities decrease westwards from 42.2 to $55.5 \mathrm{~mm} / \mathrm{yr}$ along the azimuths from $247.1^{\circ}$ to $272.5^{\circ}$. In central part of the study area, GPS stations move nearly toward the west, whereas in the Pingtung-Kaohsiung coastal area, displacement vectors demonstrate a clear counter-clockwise deviation toward the SW. The transtensional deformation and the along-strike variation of southward increase of extensional deformation is due to the low lateral confining conditions related to the Manila subduction zone as a free boundary or/and the presence of the prominent Peikang High as a rigid indentor. The Chishan Fault is dominated by right-lateral motion with a fault slip rate $\sim 7 \mathrm{~mm} / \mathrm{yr}$ in a N50 ${ }^{\circ} \mathrm{W}$ direction. The Kaoping Fault is dominated by left-lateral motion with a $\sim 4-8 \mathrm{~mm} / \mathrm{yr}$ in a $\mathrm{N}-\mathrm{S}$ direction. The significant right-lateral component of motion of $\sim 24-30 \mathrm{~mm} / \mathrm{yr}$ is accommodated along the active structures west of the Chishan Fault. The right-lateral and left-lateral structures facilitate the southwestward extrusion. The velocity gradients of the GPS stations across the Chaochou Fault are not significant. This implies that the Chaochou Fault is locked along the fault plane.
\end{abstract}

(C) 2006 Elsevier Ltd. All rights reserved.

Keywords: GPS; Crustal deformation; Active fault; Taiwan

\section{Introduction}

Space geodetic techniques, especially the global position system (GPS), have become a powerful tool for high accuracy geodetic monitoring of a wide range of geophysical phenomena such as plate motion, deformation associated with earthquakes and volcanoes, fault activity and crustal deformation at plate boundaries (Dixon, 1991; Segall and Davis, 1997). In order to quantify the kinematics of defor-

\footnotetext{
* Corresponding author. Tel.: +886223634860; fax: +886223636095

E-mail address: jchu@ntu.edu.tw (J.-C.Hu).
}

mation along the convergent plate boundary of Taiwan, the "Taiwan GPS Network" was established in 1990 with dualfrequency geodetic receivers (Yu et al., 1997; Yu and Kuo, 2001; Hickman et al., 2002). These data provided the amplitude and orientation of tectonic motion across the plate boundary of Taiwan, and hence direct constraints on geodynamics. Some limitations in the direct interpretation of such studies were later highlighted by the co-seismic deformation of the Chichi earthquake. This major earthquake clearly revealed that the inter-seismic deformation documented by the brevity of GPS surveys did not provide a complete picture of the deformation across the collision belt. The long-term deformation pattern includes a major 


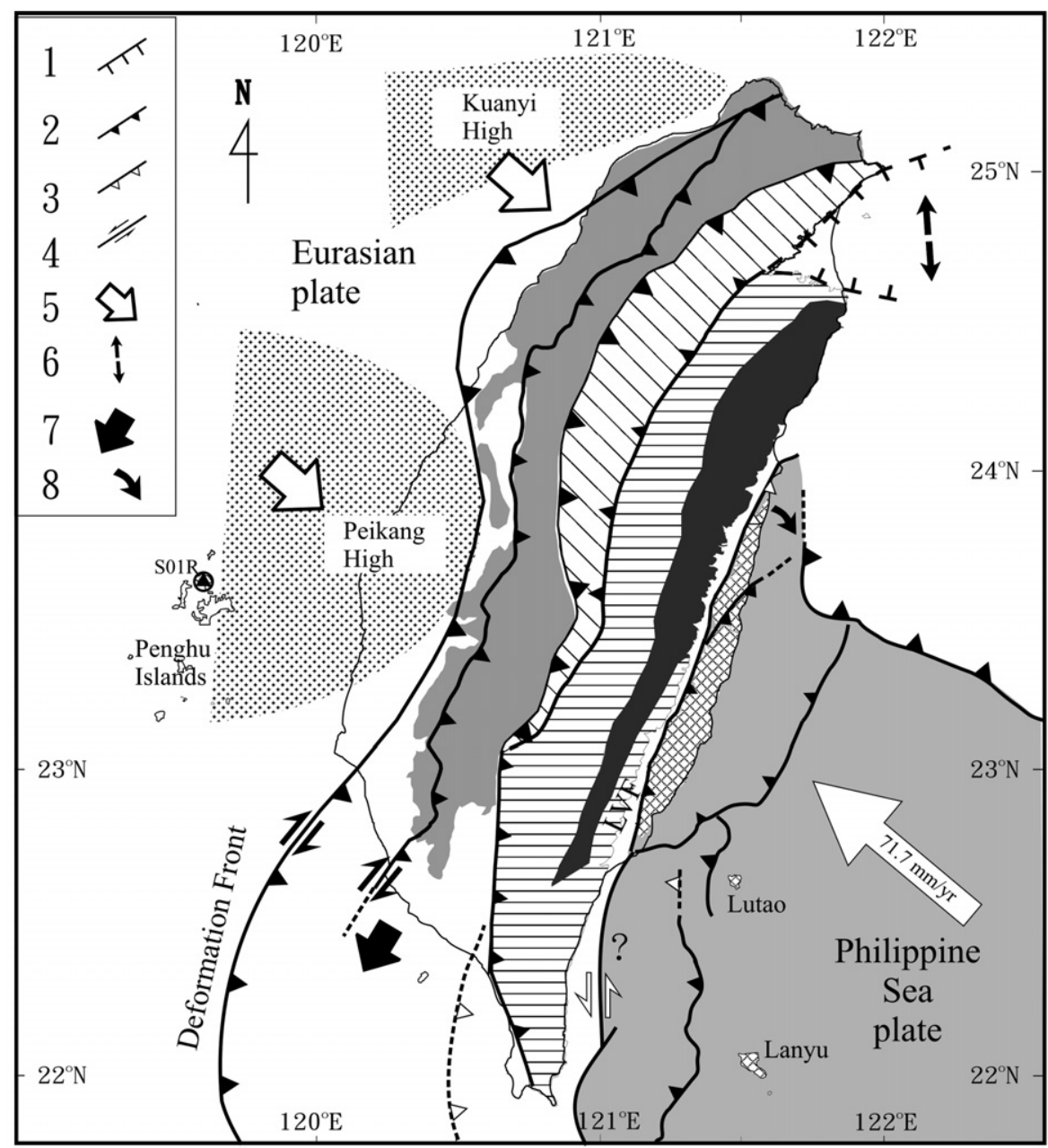

$\begin{array}{ll}\square & \text { Coastal plain } \\ & \text { Foothills } \\ \text { Quaternary-Miocene } \\ \text { Sequence }\end{array}$

Hsuehshan Range Paleogene Slate

Backbone Range Miocene-Paleogene Slate

Pre-Tertiary

metamorphic complex

Fig. 1. Tectonic framework and main structural units in Taiwan (modified after Teng, 1990; Hu et al., 2001; Lacombe et al., 2001; Malavieille et al., 2002). Large Open arrow shows the direction and velocity of plate convergence of Philippine Sea plate and Eurasian plate relative to the South China block (Yu et al., 1997, 1999). Major thrust faults with triangles are on the upthrust side. Numbers indicate 1, normal fault; 2, thrust fault (active); 3, thrust fault (inactive); 4, strike-slip fault; 5 , indenter of rigid promontory at the front of the active belt; 6 , back-arc opening; 7 , tectonic escape; 8 , migration of the thrust front.

co-seismic component of deformation, which dominates near front of the belt and highlights a double plate boundary structure (Angelier et al., 2001). A further limitation of the initial Taiwan GPS Network involved sparse coverage of GPS stations in some areas was less than comprehensive and did not permit detailed reconstruction of the deformation. This was the case in the Pingtung plain, although GPS data suggested a different present-day deformation, as compared with northern regions close to the front of the belt. To better reconstruct the ongoing deformation, a dense network was established since 1996 in the Kaohsiung and Pingtung areas. It thus became possible to monitor the crustal deformation along and around major crustal structures such as the Chaochou Fault and the Chishan Fault (Fig. 1).

The still ongoing collision between the Luzon volcanic arc and the China continental margin of Eurasian plate began ca. 5 Ma (e.g., Chai, 1972; Suppe, 1984; Angelier, 1986; Ho, 1986; Teng, 1990, 1996). This collision belt connects the Ryukyu subduction zone, where Philippine Sea plate is subducting beneath the Eurasian plate, and the Manila subduction zone, where the Philippine Sea plate is overriding the crust of South China Sea (Fig. 1). The GPS measurements and the NUVEL-1 and-1A models of global plate motion predict motion of the Philippine Sea plate toward the northwest $\left(\sim 305-310^{\circ}\right)$, at a rate of 
$70-82 \mathrm{~mm} / \mathrm{yr}$ relative to the Eurasia plate, in good directional agreement with, but at a greater velocity than the previous estimates (Seno et al., 1993; Yu et al., 1997, 1999; Zang et al., 2002). Based on geological and seismological evidence, the NNE trending Longitudinal Valley Fault is considered to be the major suture zone between the two plates (Ho, 1986; Tsai, 1986). However, field measurements of the fault displacement suggested and consideration of major thrust events to the west confirmed that it accommodates no more than $25-30 \%$ of the total convergence across the Taiwan collision belt (Angelier et al., 2000, 2001). Furthermore, the trend of the relative plate-motion vector undergoes a $15-20^{\circ}$ clockwise deviation as compared with the direction perpendicular to the structural grain of the orogenic belt, indicating a significant left-lateral component of motion. In response to this obliquity, the orogenic belt propagates southward at a rate of $\sim 55 \mathrm{~km} / \mathrm{my}$ (Suppe, 1984; Byrne and Crespi, 1997). The collision is no longer active in northernmost Taiwan and the transtensional tectonic regime prevails due to different mechanical processes ( $\mathrm{Hu}$ and Angelier, 1996; $\mathrm{Hu}$ et al., 1996, 2002; Teng, 1996). The orogenic belt of centralsouthern Taiwan is undergoing strong crustal deformation (Yu and Chen, 1994; Yu et al., 1997), rapid uplift (Liew et al., 1990; Liu and Yu, 1990; Wang and Burnett, 1990; Pirazzoli et al., 1993; Chen and Liu, 2000; Vita-Finzi, 2000; Liu et al., 2001) and high denudation and erosion rate (Li, 1976; Hovius et al., 2000; Dadson et al., 2003) in a typical compressional regime. In this paper, we discuss the tectonic behavior near the southern tip of the Taiwan belt, close to the transition zone between the mountain ranges of the collision zone and the submarine accretionary prism of the northern Manila subduction zone.

The theory of lateral extrusion along a collision zone has been documented over more than two decades ago (Molnar and Tapponnier, 1978; Tapponnier et al., 1983; Ratschbacher et al., 1991). The basic concept of tectonic extrusion refers to the lateral motion of a structural unit that moves toward a free boundary in response to collision shortening. Its application to SW Taiwan deserves discussion because it is usually considered over larger areas and generally occurs at crustal-lithospheric scales along major transcurrent faults. Southwestern Taiwan is a region where lateral extrusion is expected because it is the transition zone between the collision belt and the offshore Manila subduction zone. In more detail, this lateral extrusion is also related to both the collisional shortening and the indentation of the Peikang basement high (Fig. 1). Sandbox modeling supported the interpretation of southwestern Taiwan undergoing tectonic extrusion toward the SW ( $\mathrm{Lu}$ and Malavieille, 1994; Lu et al., 1998). The relationship between the kinematic evolution of the fold-and-thrust units of the southwestern Foothills and the offshore accretionary prism is a key topic for understanding the crustal deformation and mechanical behavior of this transition zone. The aim of this study is to examine this lateral extrusion hypothesis and the fault activity of the Pingtung area in SW Taiwan primarily based on the results of new dense GPS network data gathered from 1996 to 1999.

\section{Tectonic and geological background of Pingtung area}

Southwestern Taiwan is located on a transition zone between collision and subduction and corresponds to the southern part of the Plio-Pleistocene foreland basin in response to lithospheric flexure due primarily to the tectonic loading of the Central Range (Lin and Watts, 2002). The Western Foothills of Taiwan are composed of a series of imbricated folds and thrust sheets affected by basementinvolved tectonics (Mouthereau et al., 2002). The Pingtung plain, which covers an area of $1210 \mathrm{~km}^{2}$, exhibits a rectangular shape when mapped and viewed in cross section display fills of unconsolidated sediments of the late Pleistocene and the Holocene. Most of these sediments consist of coastal to estuarine sand and mud, with abundant shallow marine to lagoonal shells and foraminifers (Shyu, 1999; Chiang et al., 2004). The Pingtung plain is bounded by low hills of deformed Quaternary sediments to the north and the west and to the east, the plain is bounded by metamorphosed tertiary rocks of the Central Mountain Range. Based on a recent neotectonic map (Shyu et al., 2005), the Pingtung plain comprises the major element of a proposed "Kaoping domain" located between the outer-arc ridge sediments of the Central Range and the continental shelf deposits of the Western Foothills. The present-day Pingtung plain corresponds to the forearc domain between the trench to the west and the forearc ridge to the east. This more-than-100-km-wide domain has undergone major shortening and thus transformed into a fold-and-trust belt of the Western Foothills of Taiwan. To the south, numerous anticlinal ridges and minor thrust faults on the seafloor indicate the initial shortening of this forearc space (Liu et al., 1997; Lundberg et al., 1997; Lacombe et al., 1999).

Active neotectonics has been investigated by morphological data in southwestern Taiwan (Bonilla, 1975, 1977; Hsu and Chang, 1979; Shyu et al., 2005). The most significant geomorphological feature of the Pingtung plain is the straight, N-S trending Chaochou Fault escarpment separating the alluvium plain and the high mountains (Fig. 2). East of the Chaochou Fault, the mountains are mainly composed of Eocene-Miocene argillite, slate and metasandstone. The contrast between rock ages and the difference in elevation between the two sides of the Chaochou Fault highlights a major vertical relative displacement. The remarkable straight shape of this fault line in the geological maps may suggest the existence of a significant component of strike-slip motion. Thus, the Chaochou Fault is considered as a probable oblique-slip fault zone that steeply dips to the east.

Recent studies have shown that the Chaochou Fault and its adjacent areas actually experienced transtensional tectonic movements (Chan et al., 2000). Based on tectonic analysis of outcrop-scale faults, a predominant transtensional tectonic regime with NNE to NE extension and ESE 


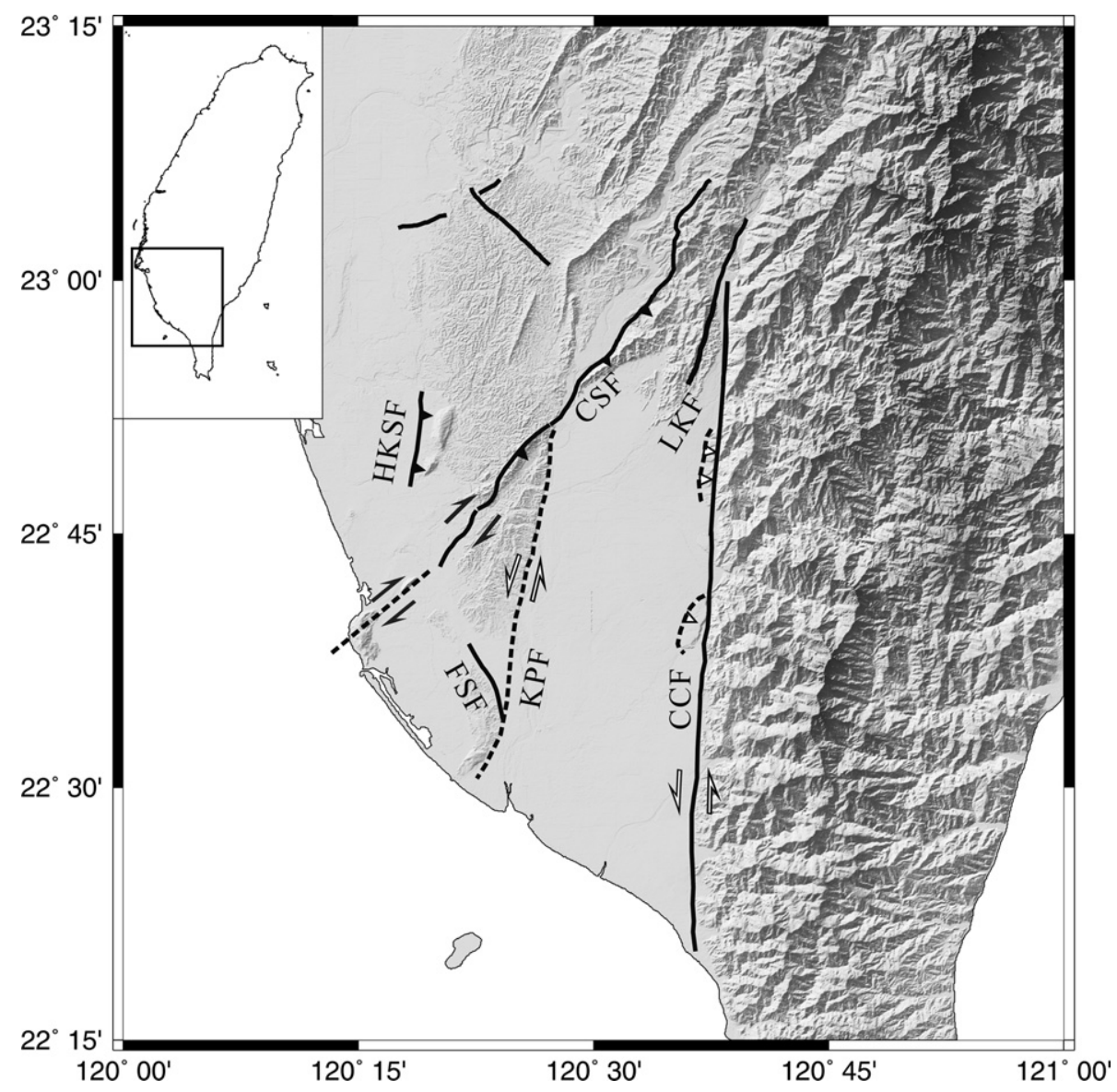

Fig. 2. Neotectonic map of southwestern Taiwan of the study area (modified after Shyu et al., 2005). Thick lines indicate the active faults (Lin et al., 2000). CCF, Chaochou Fault; CSF, Chishan Fault; LKF, Liukuei Fault; HKSF, Hsiaokangshan Fault; FSF, Fengshan Fault; and KPF, Kaoping Fault. The dashed line indicates the inferred fault. Inset shows the location of the study area.

to SE compression was reconstructed on the eastern side of the Chaochou Fault (Chan et al., 2000). The transition from transpression to recent transtension was also highlighted along the Chaochou Fault and is probably related to the transition from collision to subduction, which highlights the active extrusion of the study area towards the southeast. Within this geological framework, our geodetic (GPS) analysis aimed at a better characterization of the present-day deformation in the area.

\section{The Pingtung GPS network}

The 'Pingtung GPS Network' was established in 1995 by the Central Geological Survey, Ministry of Economic Affairs, to analyze present-day crustal deformation and land subsidence in the Pingtung area (Fig. 3). It is composed of 48 annually surveyed stations and one permanent, continuously monitoring station (S23R), covering the Pingtung and Kaohsiung area.

During the period from August 1995 to August 1999, the mobile stations of the network were surveyed 3-4 times with dual frequency geodetic GPS receivers. The changes in baseline components derived from these repeated and continuous GPS measurements provided accurate estimates of the relative velocities of GPS stations in study area. In each survey, 4-8 stations were observed simultaneously with dualfrequency geodetic receivers (Trimble 4000 SSE Geodetic Surveyor). A station was usually occupied during more than two sessions, each session being composed of 6-14 h of GPS observations to all available satellites rising higher than a $15^{\circ}$ angle of elevation. The sampling interval was $15 \mathrm{~s}$. Daily solutions were computed for continuous GPS data. The ionosphere-free linear combination of observations at the L1 and L2 frequencies were employed as the basic observation for estimating the station coordinates and baseline solutions. We have processed the observed data with the official, final and precise ephemerides distributed by the IGS.

All available temporary measurements and continuous recordings of GPS data were processed with the Bernese GPS software (v.4.2) developed at the Astronomical Institute of the University of Berne (Hugentobler et al., 2001). The observed data in each epoch survey were processed session by session to obtain the baseline solutions for all combinations of any two stations in the same session. The scatter of series of GPS measurements taken over several years can be employed as an indicator of precision. This long-term repeatability shows the effects of slowly varying systematic errors due to propagation delay, multipath, or 

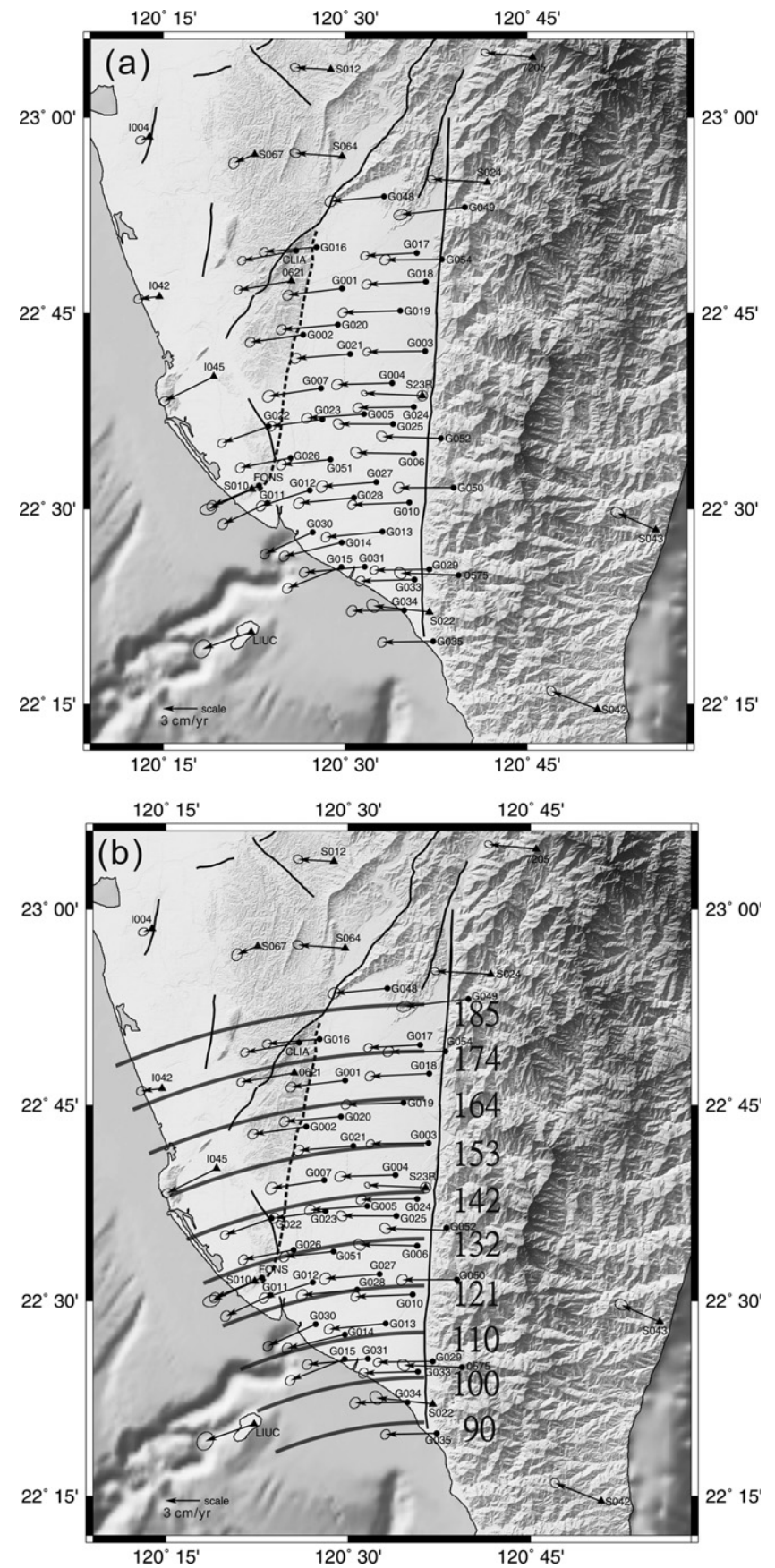

Fig. 3. (a) The velocities of GPS stations on the Pingtung plain relative to Paisha, Penghu (S01R) from 1996 to 1999. Location of S01R in Fig. 1. The $95 \%$ confidence ellipse is shown at the tip of each velocity vector. Solid triangle inside circle indicates permanent station. Solid triangles indicate the GPS stations of Academia Sinica (Yu et al., 1997). Thick lines are active faults. Shaded topography is based on $40 \mathrm{~m} \times 40 \mathrm{~m}$ DEM. (b) The fit between trends of velocity vectors and concentric circles, with centre near $21^{\circ} 50^{\prime} \mathrm{N}-120^{\circ} 36^{\prime} \mathrm{E}$. Bold numbers indicate the linear velocity expected for each circle, in percentage relative to the velocity at Liuchiu (LIUC). See text for discussion.

fiducial network inconsistencies. The repeatability of a baseline component (east, north, and vertical) or baseline length is given by the root-mean-square scatter about the linear trend. The baselines range from 3 to $21 \mathrm{~km}$ in length, with the majority shorter than $10 \mathrm{~km}$.
The average rates of length change on each baseline between nearby stations, which are usually observed in the same session, were determined by linear regression in time. Considering this and the relative geological stability of the Penghu area, the coordinates of Paisha station (S01R) and the azimuth from Paisha to Taipei $\left(\mathrm{N} 52.1^{\circ} \mathrm{E}\right)$ were fixed in the least-square adjustment to estimate the station velocities. This procedure was compulsory for resolving the translational and rotational ambiguities of the whole network in the estimation that follows. The individual values of the average length rate from the 548 baselines in the Taiwan GPS Network were weighted by the reciprocal square of the standard error in the rate. These weighted rates were then used in a least squares adjustment to estimate the station velocities relative to the fixed station S01R.

\section{Kinematics of lateral extrusion and fault activity inferred from GPS data}

Our GPS surveys have provided a complete velocity field of SW Taiwan. In all illustrations in this paper, this velocity field is shown relative to the Paisha station of the Penghu islands, which is considered as the stable continental shelf (with additional consideration of a fixed direction Paisha, Taipei). Horizontal GPS displacement velocities in the investigated area are listed in Table 1 . The station velocities are $42.2-55.5 \mathrm{~mm} / \mathrm{yr}$ along the azimuths from $244.7-272.5^{\circ}$. The horizontal GPS velocity vectors are shown in Fig. 3, with respect to the local frame of a permanent station (S01R) located in the stable continental shelf. The station velocities generally decrease westward and increase southward.

At first sight, the pattern of velocity vector trends is regular and consistent with small circles around a common pole located near $21^{\circ} 50^{\prime} \mathrm{N}-120^{\circ} 36^{\prime} \mathrm{E}$ (Fig. 3b). Despite this directional consistency, the present-day displacement of this region cannot be interpreted in terms of rigid rotation. This impossibility is illustrated by the comparison between expected and observed velocities along different circles. Assuming rigid rotation, the velocity found at the northern stations of the Pingtung plain should be twice as large as in the southern stations. This contradicts the southward increase in velocity noted above. The displacement pattern is more complex than rigid rotations and rather resembles a flow of particles towards an open edge (in this case the area offshore in southwestern Taiwan) with increasing velocity towards the weakest domain.

In terms of velocity vector trends, there is a striking contrast in kinematics between two subareas. In the central and western part of the study area, GPS stations are generally moving toward the west, whereas in the Kaohsiung and Pingtung coastal area the displacement vectors of four stations (FONS, G011, G030 and G014) reveal a counterclockwise deviation toward the SW. The station velocities of these four stations vary between 42.2 and $51.0 \mathrm{~mm} / \mathrm{yr}$, in azimuths ranging from $244.7^{\circ}$ to $256.5^{\circ}$. These results show the same general trends as the previous GPS measurements 
Table 1

Velocities of GPS stations in Pingtung area

\begin{tabular}{|c|c|c|c|c|c|c|}
\hline Station & Lon. $\left(^{\circ}\right)$ & Long. $\left({ }^{\circ}\right)$ & $V_{\mathrm{e}}(\mathrm{mm} / \mathrm{yr})$ & $V_{\mathrm{n}}(\mathrm{mm} / \mathrm{yr})$ & $\mathrm{V}(\mathrm{mm} / \mathrm{yr})$ & Azimuth $\left(^{\circ}\right)$ \\
\hline CLIA & 120.4324 & 22.8300 & $-46.5 \pm 1.5$ & $-8.5 \pm 1.5$ & $47.2 \pm 1.4$ & $259.7 \pm 1.6$ \\
\hline FONS & 120.3817 & 22.5300 & $-40.7 \pm 1.7$ & $-17.3 \pm 1.7$ & $44.2 \pm 2.5$ & $247.0 \pm 1.6$ \\
\hline G001 & 120.4959 & 22.7817 & $-46.7 \pm 1.7$ & $-5.7 \pm 1.7$ & $47.0 \pm 2.2$ & $263.0 \pm 1.7$ \\
\hline G002 & 120.4425 & 22.7230 & $-45.7 \pm 1.7$ & $-6.6 \pm 1.7$ & $46.2 \pm 2.2$ & $261.8 \pm 1.6$ \\
\hline G003 & 120.6098 & 22.7020 & $-50.0 \pm 1.4$ & $-0.6 \pm 1.4$ & $50.0 \pm 1.8$ & $269.3 \pm 1.2$ \\
\hline G004 & 120.5646 & 22.6612 & $-47.3 \pm 1.9$ & $-1.3 \pm 1.8$ & $47.3 \pm 2.3$ & $268.4 \pm 1.8$ \\
\hline G005 & 120.5258 & 22.6213 & $-49.1 \pm 1.8$ & $-3.4 \pm 1.7$ & $49.2 \pm 2.3$ & $266.0 \pm 1.5$ \\
\hline G006 & 120.5943 & 22.5707 & $-49.4 \pm 1.9$ & $0.9 \pm 1.9$ & $49.4 \pm 2.3$ & $271.0 \pm 1.9$ \\
\hline G007 & 120.4667 & 22.6543 & $-45.0 \pm 2.1$ & $-6.8 \pm 2.0$ & $45.5 \pm 2.6$ & $261.4 \pm 2.0$ \\
\hline G010 & 120.5884 & 22.5085 & $-49.3 \pm 1.5$ & $-1.9 \pm 1.6$ & $49.3 \pm 2.1$ & $267.7 \pm 1.3$ \\
\hline G011 & 120.3930 & 22.5075 & $-38.2 \pm 1.7$ & $-18.0 \pm 1.9$ & $42.2 \pm 2.6$ & $244.7 \pm 1.6$ \\
\hline G012 & 120.4515 & 22.5241 & $-42.0 \pm 1.7$ & $-13.6 \pm 1.8$ & $44.1 \pm 2.5$ & $252.0 \pm 1.6$ \\
\hline G013 & 120.5512 & 22.4713 & $-48.6 \pm 1.6$ & $-4.77 \pm 1.7$ & $48.8 \pm 2.2$ & $264.4 \pm 1.5$ \\
\hline G014 & 120.4955 & 22.4572 & $-49.6 \pm 1.7$ & $-11.9 \pm 1.8$ & $51.0 \pm 2.2$ & $256.5 \pm 1.5$ \\
\hline G015 & 120.4948 & 22.4258 & $-46.4 \pm 1.7$ & $-18.3 \pm 1.7$ & $49.8 \pm 2.3$ & $248.4 \pm 1.5$ \\
\hline G016 & 120.4608 & 22.8346 & $-45.3 \pm 1.6$ & $-4.11 \pm 1.5$ & $45.5 \pm 2.1$ & $264.8 \pm 1.4$ \\
\hline G017 & 120.5983 & 22.8272 & $-44.5 \pm 1.5$ & $-2.5 \pm 1.4$ & $44.5 \pm 2.2$ & $266.8 \pm 1.3$ \\
\hline G018 & 120.6107 & 22.7907 & $-50.7 \pm 1.7$ & $-2.4 \pm 1.6$ & $50.7 \pm 2.0$ & $267.3 \pm 1.5$ \\
\hline G019 & 120.5758 & 22.7536 & $-49.3 \pm 1.6$ & $-1.6 \pm 1.6$ & $49.4 \pm 2.1$ & $268.1 \pm 1.5$ \\
\hline G020 & 120.4899 & 22.7356 & $-48.5 \pm 1.7$ & $-4.3 \pm 1.7$ & $48.6 \pm 2.2$ & $265.0 \pm 1.5$ \\
\hline G021 & 120.5069 & 22.6982 & $-46.8 \pm 1.8$ & $-3.8 \pm 1.8$ & $47.0 \pm 2.3$ & $265.3 \pm 1.7$ \\
\hline G022 & 120.3947 & 22.6057 & $-40.0 \pm 1.5$ & $-14.4 \pm 1.5$ & $42.5 \pm 2.3$ & $250.2 \pm 1.3$ \\
\hline G023 & 120.4686 & 22.6147 & $-44.2 \pm 1.7$ & $-6.0 \pm 1.7$ & $44.6 \pm 2.4$ & $262.3 \pm 1.6$ \\
\hline G024 & 120.5946 & 22.6305 & $-48.2 \pm 1.7$ & $-0.7 \pm 1.7$ & $48.2 \pm 2.1$ & $269.2 \pm 1.5$ \\
\hline G025 & 120.5660 & 22.6086 & $-47.0 \pm 1.8$ & $0.1 \pm 1.7$ & $47.0 \pm 2.3$ & $270.2 \pm 1.7$ \\
\hline G026 & 120.4251 & 22.5652 & $-43.3 \pm 1.6$ & $-8.4 \pm 1.7$ & $44.1 \pm 2.3$ & $259.1 \pm 1.5$ \\
\hline G027 & 120.5430 & 22.5344 & $-46.8 \pm 1.9$ & $-3.8 \pm 2.0$ & $47.0 \pm 2.6$ & $265.4 \pm 1.8$ \\
\hline G028 & 120.5123 & 22.5146 & $-47.4 \pm 1.9$ & $-4.7 \pm 2.0$ & $47.6 \pm 2.5$ & $264.3 \pm 1.8$ \\
\hline G029 & 120.6159 & 22.4229 & $-47.4 \pm 1.4$ & $-0.8 \pm 1.5$ & $47.4 \pm 2.2$ & $269.1 \pm 1.2$ \\
\hline G030 & 120.4553 & 22.4702 & $-41.0 \pm 1.7$ & $-18.8 \pm 1.7$ & $45.1 \pm 2.4$ & $245.4 \pm 1.5$ \\
\hline G031 & 120.5266 & 22.4263 & $-51.8 \pm 1.7$ & $-5.0 \pm 1.7$ & $52.0 \pm 2.2$ & $264.5 \pm 1.5$ \\
\hline G033 & 120.5952 & 22.4095 & $-46.6 \pm 1.6$ & $-1.1 \pm 1.7$ & $46.6 \pm 2.3$ & $268.6 \pm 1.4$ \\
\hline G034 & 120.5812 & 22.3704 & $-45.1 \pm 1.8$ & $-0.5 \pm 1.9$ & $45.1 \pm 2.7$ & $269.4 \pm 1.6$ \\
\hline G035 & 120.6209 & 22.3306 & $-43.8 \pm 1.6$ & $-0.9 \pm 1.7$ & $43.8 \pm 2.5$ & $268.9 \pm 1.3$ \\
\hline G048 & 120.5536 & 22.8994 & $-45.8 \pm 2.0$ & $-4.2 \pm 1.9$ & $46.0 \pm 2.5$ & $264.7 \pm 1.9$ \\
\hline G049 & 120.6646 & 22.8855 & $-55.1 \pm 2.5$ & $-6.49 \pm 1.8$ & $55.5 \pm 2.6$ & $263.3 \pm 1.8$ \\
\hline G050 & 120.6491 & 22.5274 & $-47.3 \pm 1.9$ & $-0.1 \pm 1.9$ & $47.3 \pm 2.4$ & $269.8 \pm 1.8$ \\
\hline G051 & 120.4799 & 22.5631 & $-42.2 \pm 1.7$ & $-4.5 \pm 1.8$ & $42.5 \pm 2.6$ & $263.9 \pm 1.6$ \\
\hline G052 & 120.6319 & 22.5907 & $-50.7 \pm 1.9$ & $1.4 \pm 1.8$ & $50.7 \pm 2.3$ & $271.6 \pm 1.8$ \\
\hline G054 & 120.6330 & 22.8191 & $-48.9 \pm 1.8$ & $-0.4 \pm 1.7$ & $48.9 \pm 2.2$ & $269.5 \pm 1.6$ \\
\hline 0575 & 120.6557 & 22.4156 & $-49.9 \pm 2.0$ & $1.7 \pm 2.0$ & $49.9 \pm 2.5$ & $271.9 \pm 1.9$ \\
\hline S23R & 120.6061 & 22.6449 & $-49.9 \pm 1.0$ & $2.1 \pm 1.0$ & $49.9 \pm 1.6$ & $272.5 \pm 0.6$ \\
\hline I042 & 120.2446 & 22.7718 & $-17.9 \pm 1.6$ & $-2.1 \pm 1.6$ & $18.0 \pm 1.6$ & $263.3 \pm 1.6$ \\
\hline $\mathrm{I} 045$ & 120.3194 & 22.6694 & $-42.4 \pm 1.8$ & $-21.2 \pm 1.6$ & $47.4 \pm 1.8$ & $243.4 \pm 1.6$ \\
\hline LIUC & 120.3707 & 22.3427 & $-41.9 \pm 2.9$ & $-14.7 \pm 3.2$ & $44.4 \pm 2.9$ & $250.7 \pm 3.2$ \\
\hline 0621 & 120.4258 & 22.7915 & $-45.6 \pm 1.4$ & $-7.8 \pm 1.5$ & $46.3 \pm 1.4$ & $260.3 \pm 1.5$ \\
\hline S010 & 120.3718 & 22.5254 & $-37.3 \pm 3.0$ & $-17.1 \pm 2.0$ & $41.0 \pm 2.8$ & $245.4 \pm 2.2$ \\
\hline S022 & 120.6157 & 22.3683 & $-48.2 \pm 2.2$ & $5.3 \pm 2.3$ & $48.5 \pm 2.2$ & $276.3 \pm 2.3$ \\
\hline S064 & 120.4957 & 22.9504 & $-37.3 \pm 3.0$ & $-17.1 \pm 2.0$ & $41.0 \pm 2.8$ & $245.4 \pm 2.2$ \\
\hline
\end{tabular}

Note: I042, I045, LIUC, 0621, S010 and S064 are the data from Yu et al. (1997).

from 1990 to 1995 at stations I045, S010 and LIUC (Yu et al., 1997).

The numerical distinct-element models proposed by $\mathrm{Hu}$ et al. $(1997,2001)$ to account for the kinematics of anticlockwise rotation of velocity field in SW Taiwan depend on three major factors: (1) the major faults and deformation front behaving as weak discontinuities; (2) the presence of the prominent Peikang High acting as a rigid indentor of the Chinese passive margin and (3) the presence of an offshore zone of mechanical weakness including the Manila trench and the related accretionary prism.

\subsection{The activity of the Chaochou Fault}

In order to investigate the activity of the Chaochou Fault zone that trends N-S, we thus use both the E-W and N-S GPS components to characterize the fault-normal and fault-parallel kinematics, respectively. The results of this analysis are summarized in Figs. 4-6.

As Fig. 4 shows, the E-W components of station velocities relative to the stable shelf of the Taiwan Strait vary from $-38.1 \pm 1.7 \mathrm{~mm} / \mathrm{yr}$ to $-55.1 \pm 1.8 \mathrm{~mm} / \mathrm{yr}$ (the negative sign indicates westward motion). Remarkably, the absolute 


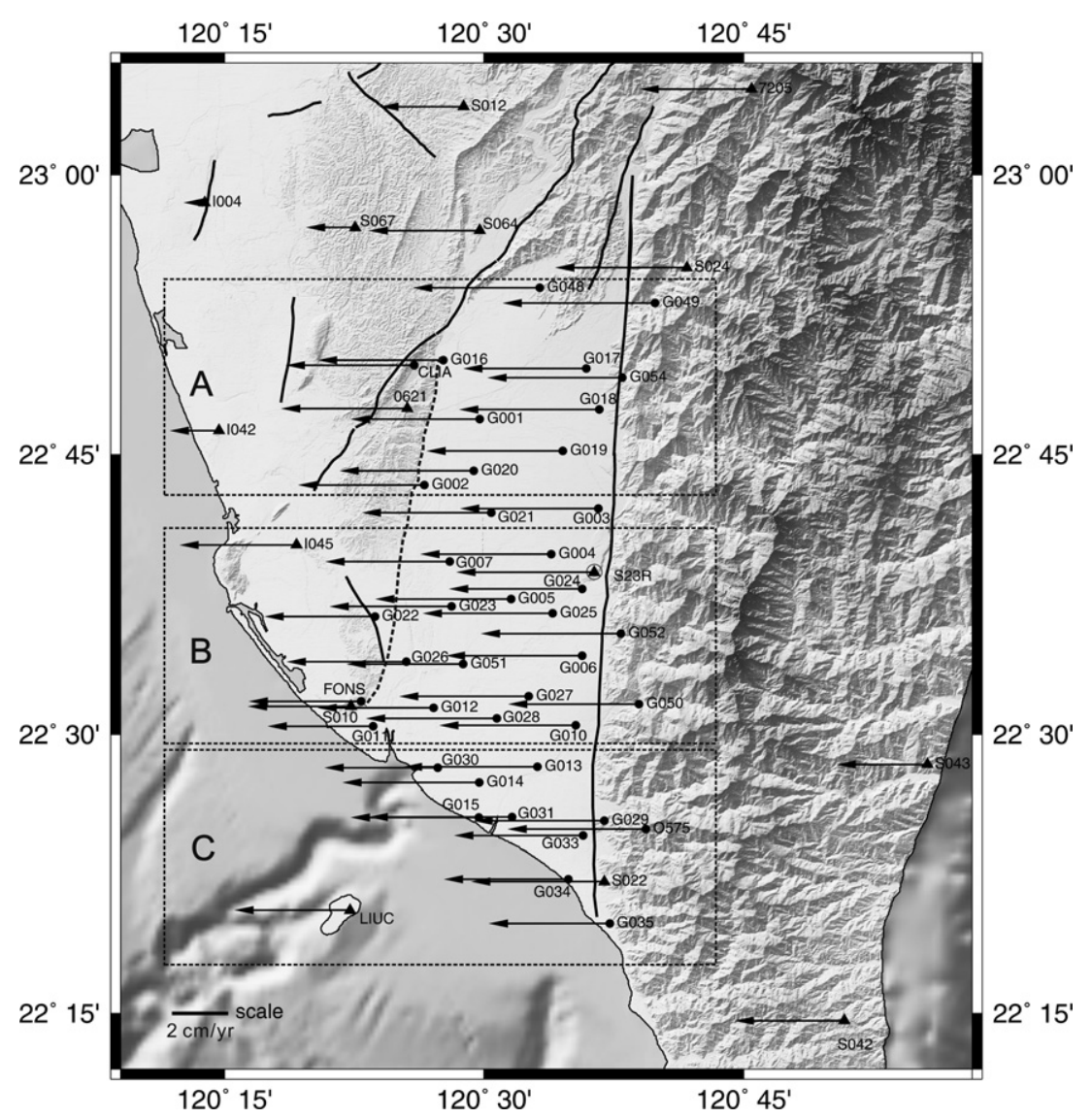

Fig. 4. E-W velocity components of GPS stations on the Pingtung plain relative to Paisha, Penghu, from 1996 to 1999 . Same symbols as in Fig. 3.

values of station velocities gradually decrease from east to west, as the profiles of Fig. 5 shown. Most especially, there is no obvious contrast in velocity across the Chaochou Fault. As mentioned above, the Chaochou Fault is the major fault in the studied area and is considered as a steeply dipping thrust fault with a significant left-lateral movement.

We divided the whole study region into three subdomains (northern, central and southern) shown as rectangular frames A, B and C in Fig. 4. Our results indicate that the E-W velocity gradients of the GPS stations across the Chaochou Fault observed in three subdomains are not significant (Figs. 4 and 5). This result shows that the transverse component of motion across the Chaochou Fault, which was expected to be extensional according to geological analysis of fault zone evolution, is minor at present day. One should note, however, that our results reflect the deformation of the interseismic stage; because the possibility of major co-seismic motion of the Chaochou Fault is left open, these results should not be extrapolated to the longterm deformation.

As for the N-S components of station velocities in the study area (Fig. 6), the station velocities vary from $2.1 \pm 2.0 \mathrm{~mm} / \mathrm{yr}$ to $-18.8 \pm 1.7 \mathrm{~mm} / \mathrm{yr}$ (the negative sign indicates southward motion). Only nine stations (G052, G006, O575, G025, S23R, S024, S012, S022 and S064) show northward movement, with station velocities smaller than
$2.1 \mathrm{~mm} / \mathrm{yr}$, and hence not significant. The other forty stations show southward movement with various velocity values. Remarkably, the southward station velocities are larger in the southwestern coastal area than in other regions. The maximum southward station velocity observed is $18.8 \pm 1.7 \mathrm{~mm} / \mathrm{yr}$. In detail, Fig. 6 shows that the increase in the N-S component of station velocities occurs in the NESW direction near the southwestern coast, rather than from North to South (compare for instance stations I045 and G034). For this reason, this aspect will be discussed in the next section, based on observation of NW and SE-directed components of motion. In any case, this general velocity pattern fits well with the hypothesis of lateral extrusion related to the ongoing ESE-WNW collision.

Examining the expected strike-slip, left-lateral component of motion along the Chaochou Fault, it appears that the present day gradients of $\mathrm{N}-\mathrm{S}$ station velocities across the Chaochou Fault zone are minor and inconsistent in sense (Fig. 6). It should again be kept in mind that these 1996-1999 results do not preclude the possibility of large co-seismic motion occurring from time to time along the fault.

Based on the strike-slip and dip-slip components of GPSderived station velocities, the Chaochou Fault should be considered as inactive during the 1996-1999 survey period. We infer that the Chaochou Fault may be locked with a strong mechanical coupling across the fault zone. However, the 

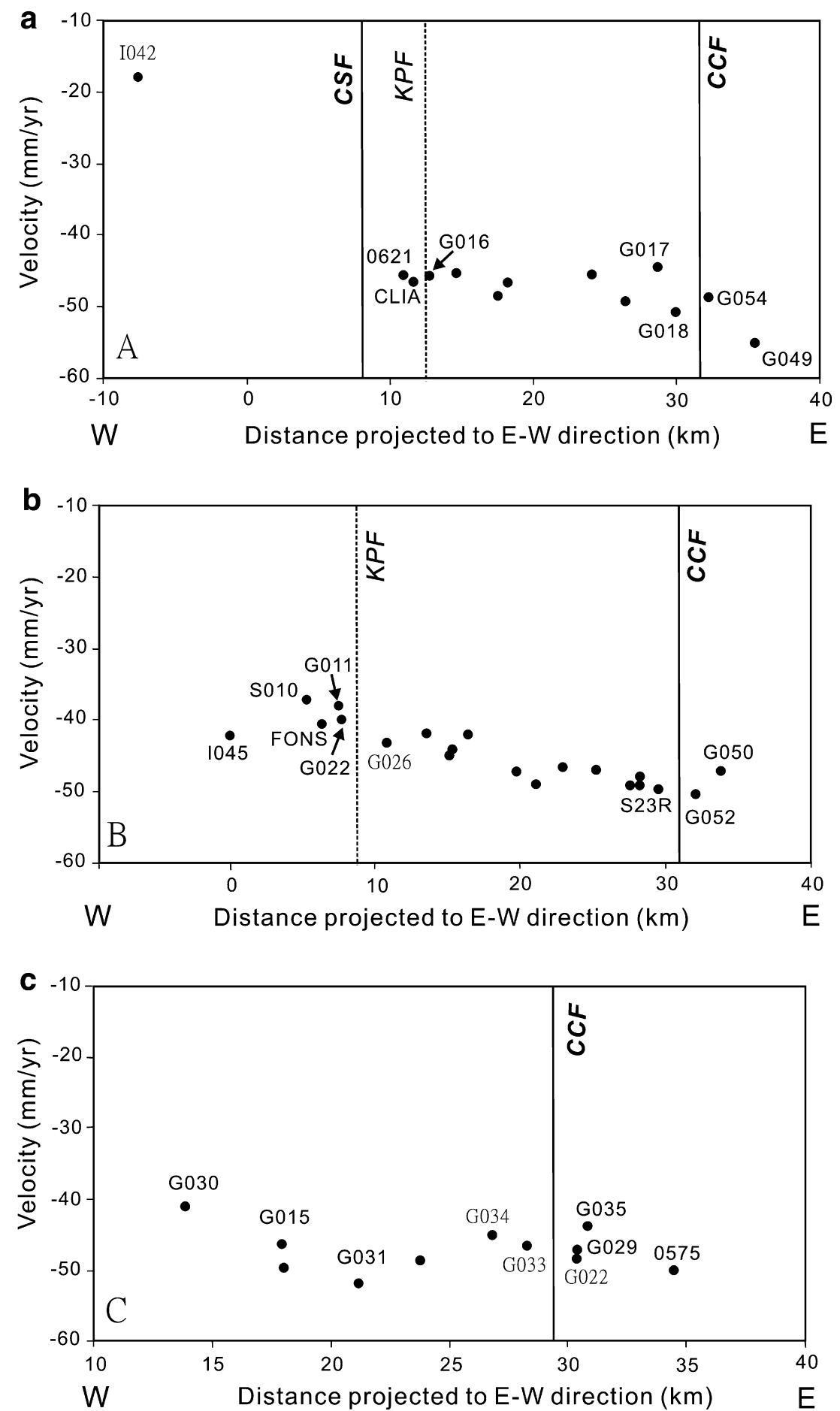

Fig. 5. Profiles of E-W components of station velocities along three subdomains of study area. CCF, Chaochou Fault; KPF, Kaoping Fault, CSF, Chishan Fault. Subdomains A, B and C are shown in Fig. 4.

absence of a dense network of GPS stations in the mountainous region east of the Chaochou Fault precludes further analysis in terms of possible locking depth and fault geometry.

\subsection{Activity of the Kaoping Fault}

On the assumption of approximately rigid block limited by major structural discontinuities such as the Chaochou Fault, the inferred Kaoping Fault, the Chishan Fault and the front thrust fault (i.e., deformation front), Lacombe et al. (2001) proposed the present-day kinematics of SW Taiwan is both undergoing the shorting and lateral escape. These authors took into account the fault-perpendicular and fault-parallel components of block motion deduced form the previous GPS data ( $\mathrm{Yu}$ et al., 1997). They suggested the existence of left-lateral Kaoping Fault based on the change in azimuth of station velocities (S022, S23R in block 1 and 0621, LIUC, S010, I045 in block 2) across the 


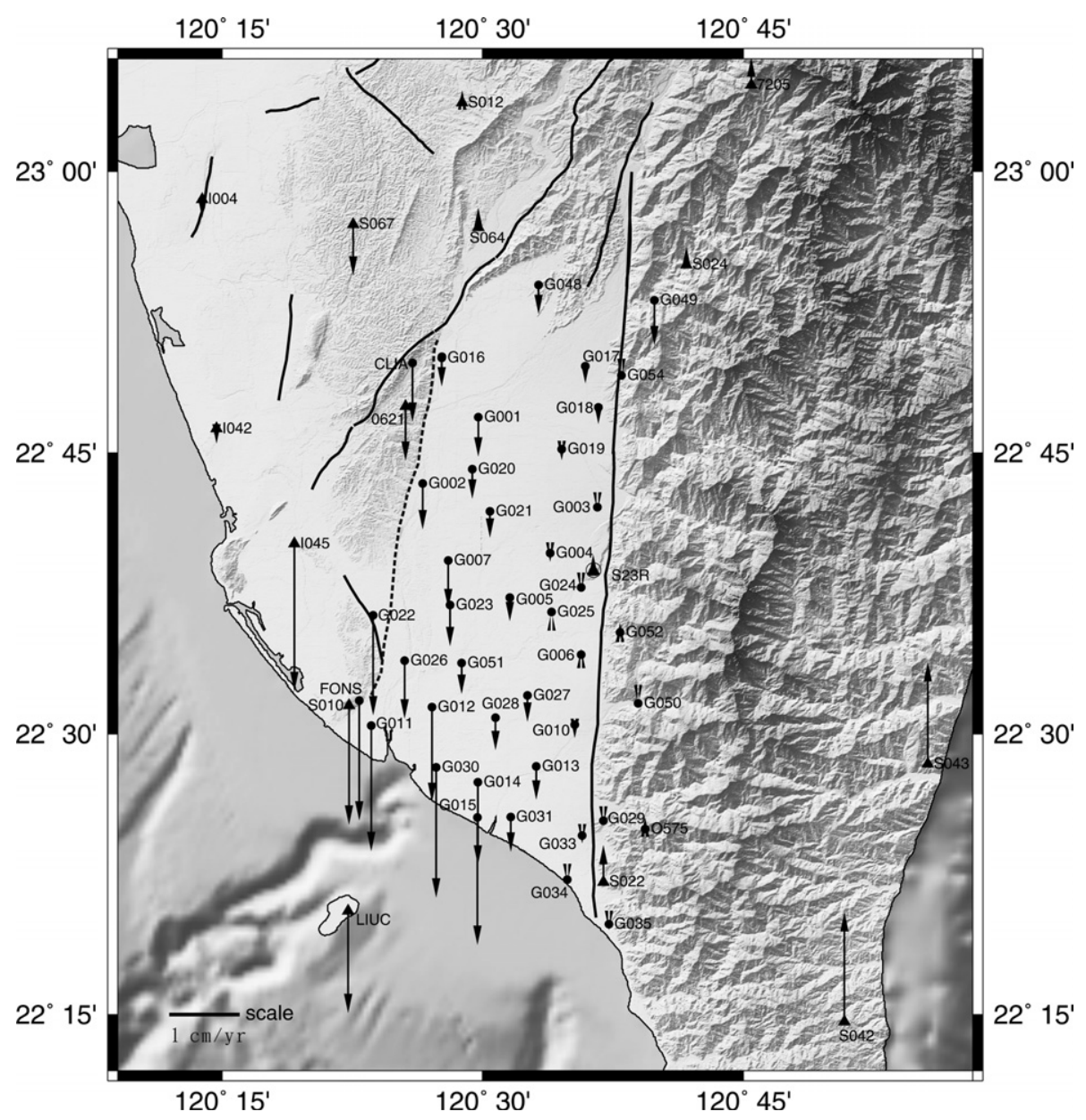

Fig. 6. N-S velocity components of GPS stations on the Pingtung plain relative to Paisha, Penghu, from 1996 to 1999. Same symbols as in Fig. 3.

fault. However, a major limitation in this approach resulted from the large spacing between the GPS stations, which were few at this time. We undertook a similar analysis with our denser network of GPS stations in the PingtungKaohsiung area.

Considering the across-strike components first (Figs. 4 and 5), we plotted the E-W components of horizontal displacement because the trends of the Chaochou Fault and the inferred Kaoping Fault are nearly N-S (Fig. 2). Our results show the across-strike components are not significant with a value of less than $\sim 5 \mathrm{~mm} / \mathrm{yr}$ by considering the velocity gradient of stations G011 and G026. If we consider the velocity gradient of stations in the northern part (CLIA, 0621 and G016) and the southern part (G022, G011 and G026) for the along-strike components of the Kaoping Fault, the left-lateral velocity increases southward from $\sim 4 \mathrm{~mm} / \mathrm{yr}$ to $\sim 8 \mathrm{~mm} / \mathrm{yr}$ based on geomorphological analysis. Shyu et al. (2005) proposed that the western side of the Pingtung plain is also a distinct topographic break (Fig. 2) and pointed out that this linear feature is likely to be modified by erosion of the Kaoping River, the major river of the Pingtung plain. Furthermore, the analysis of Holocene sediment thickness form the cores retrieved from the Pingtung plain suggest that pre-Quaternary rocks are more than $200 \mathrm{~m}$ lower in the basin located at the east side of the Kaoping Fault than in the hills to the west (Shyu, 1999). This observation implies that the Kaoping Fault is a fault with at least several hundred meters of vertical slip, and separates the rocks of the hills from those of the basin. Contrary to the Chaochou Fault on the opposite edge of the Pingtung basin, where hard basement rocks crop out, the Kaoping Fault affects relatively soft formations of the Late Paleozoic on both its sides. As a consequence, the fault escarpment has undergone significant erosion by the Kaoping River and westward retreat, so that the present-day topography provides little evidence of fault scarp.

\subsection{Evidence of lateral extrusion}

We further investigated the deformation pattern in the study area, in relation to the pattern of ESE-WNW collision. We accordingly decomposed the stations velocities into two components, plate-motion-perpendicular component (Figs. 7, 8) and the plate-motion-parallel-component (Figs. 9, 10). The direction of plate motion between the Philippine Sea plate and Eurasia is $310^{\circ}$ based on the NUVEL-1 model (Seno et al., 1993). As a consequence, the two components considered display azimuths of $040^{\circ}$ and $130^{\circ}$. 


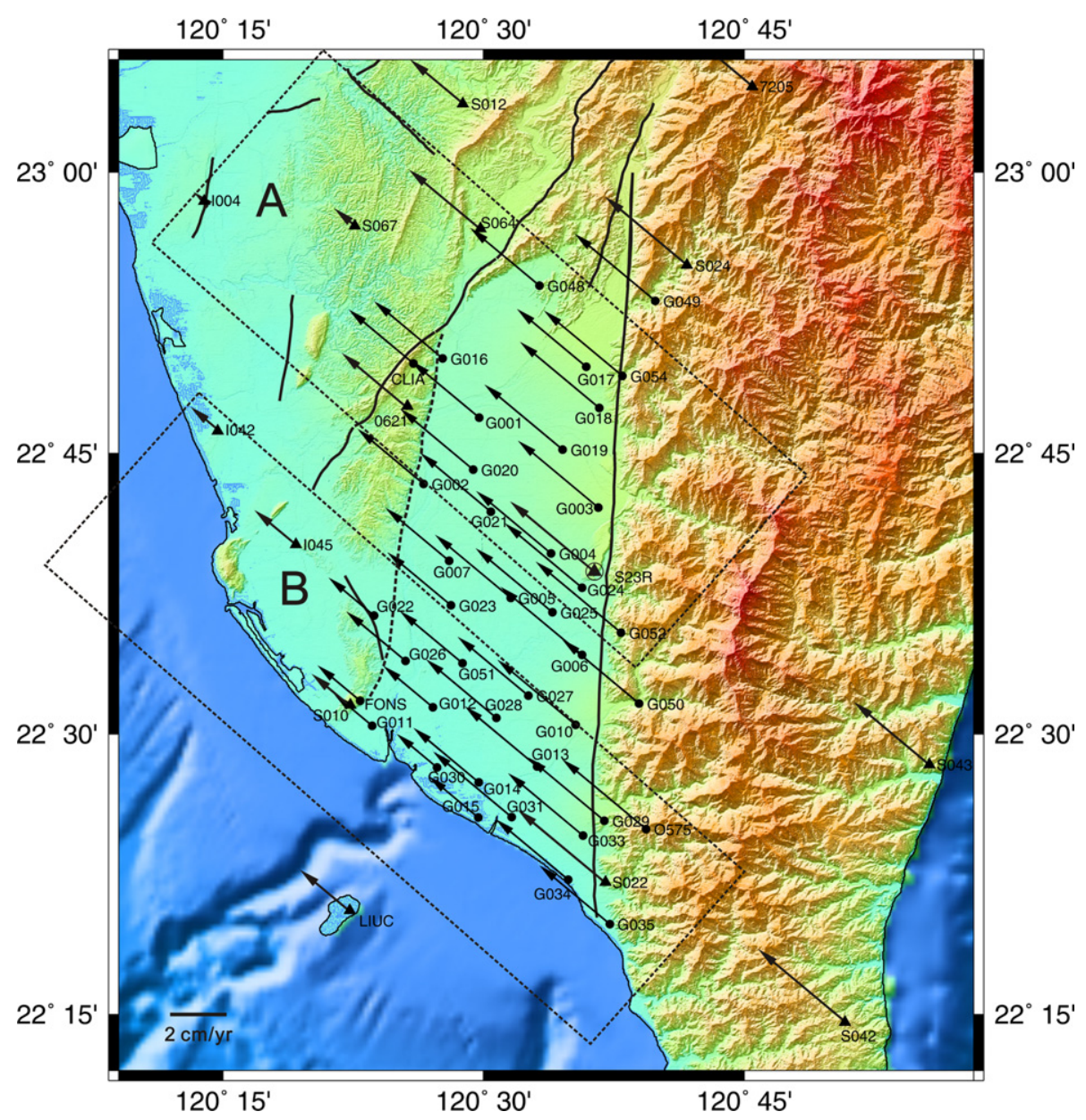

Fig. 7. Plate-motion-parallel components of GPS stations on the Pingtung plain relative to Paisha, Penghu (S01R), from 1996 to 1999 . Dotted rectangles are the domains of the profiles. Symbols are the same as in Fig. 3.

This decomposition of station velocities also facilitated the investigation of activity of the Chishan Fault because of the trend of this fault is parallel or subparallel to the plate motion. Based on the plate-motion-parallel components, the station velocities decrease northwestward from 39.9 to $17.7 \mathrm{~mm} / \mathrm{yr}$ (Figs. 7 and 8). An abrupt decrease apparently occurs around the Chishan Fault (Figs. 7 and 8, domain A) but the large spacing between stations precludes clearer identification of any velocity discontinuity. To the south, where the Chihshan Fault disappears near a zone of transfer faulting, the Fengshan transfer zone (Deffontaines et al., 1997), the station velocities decrease northwestward in a more gradual way. Taking the earlier IES stations into account (Yu et al., 1997), a significant difference in station velocity is located between stations S064 and S067 as well as between stations I042 and I045. Presently available GPS data thus allow identification of a SE-NW shortening of about $20 \mathrm{~mm} / \mathrm{yr}$ and accommodated within an about 10 $\mathrm{km}$-wide deformation zone.

Considering the plate-motion-perpendicular components (Figs. 9 and 10), the station velocities increase southwestward, from 28.7 to $44 \mathrm{~mm} / \mathrm{yr}$. An abrupt contrast in velocity apparently occurs across the southwest extension of the Chishan Fault zone near the coast (Figs. 9 and 10, domain B), whereas to the north the change is smoother across the Chishan Fault itself (Figs. 9 and 10, domain B). This pattern of the plate-motion-perpendicular station velocities is consistent with the lateral extrusion that is expected to increase towards the southwest. However, there exists a strong possibility of a Chihshan Fault being locked in the interseismic stage, while motion occurs to the south along, and south of, the Fengshan transform fault zone.

The analogue models of $\mathrm{Lu}$ and Malavieille (1994) also suggested a southward lateral extrusion of the southern Western Foothills in response to the oblique collision between the Philippines Sea plate and Eurasian plate. Based on numerical simulations, $\mathrm{Hu}$ et al. $(1997,2001)$ pointed out that the significant counter-clockwise rotations of station velocities on the coastal area of the Pingtung plain is a result of lateral extrusion. Our results clearly demonstrate that the transtensional deformation and the plate-motionnormal variation of southwestward increase of extensional deformation in the whole area of the Pingtung plain. Based on Quaternary paleostress analysis (Lacombe et al., 1999, 2001), the significant southward increase in the occurrence of extension features which corresponds most nearly with the N-S extension during last stage of fold development. They pointed out that the tectonic escape might result from 

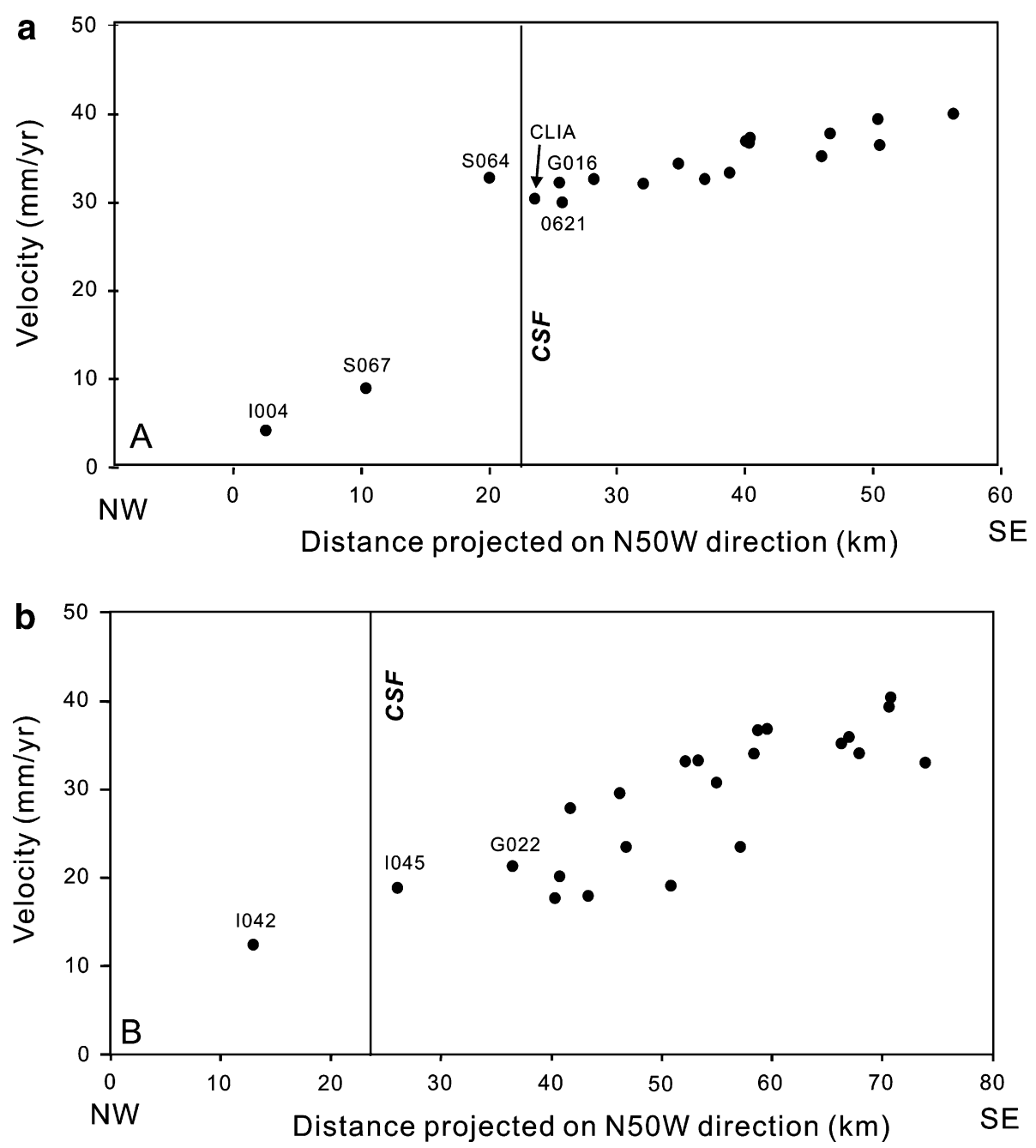

Fig. 8. Plate-motion-parallel components of station velocities along two profiles of the study area. CSF, Chishan Fault. Domains of profiles A, and B are shown in Fig. 7.

the decreasing of a N-S confinement during the last $\mathrm{E}-\mathrm{W}$ shortening in Pleistocene.

Based on the inversion of fault slip and continuous deformation deduced from GPS data in Taiwan (Yu et al., 1997), Bos et al. (2003) also presented a surface deformation model for southern Taiwan. This model exhibited a strain pattern with $\mathrm{E}-\mathrm{W}$ contraction accompanied by a southward increase of predominantly $\mathrm{N}-\mathrm{S}$ oriented extension. They found a right-lateral thrust motion of $\sim 14 \mathrm{~mm} /$ $\mathrm{yr}$ in a $\mathrm{N} 54^{\circ} \mathrm{W}$ direction in the deformation front zone, and a left-lateral normal motion of $6-13 \mathrm{~mm} / \mathrm{yr}$ in the a $\mathrm{N} 110^{\circ}$ $130^{\circ} \mathrm{E}$ direction in the Chaochou Fault zone. The major block bounded by these faults is subject to counter-clockwise rotation at a rate of about 12.5\% $\mathrm{Ma}$ (Bos et al., 2003), whereas the areas east and west of this block are undergoing significantly smaller counter-clockwise rotation rates, or even clockwise rotation. The authors suggested these patterns of surface deformation are indicative of lateral extrusion toward the Manila accretionary wedge south of Taiwan. Our results of plate-motion-normal component (Figs. 9 and 10), the right-lateral strike-slip motion along the Chishan Fault in domains A, is $\sim 7 \mathrm{~mm} / \mathrm{yr}$ by taking two adjacent stations S064 and CLIA (Fig. 10a) across the fault into account. However, if we take I045 and I042 into account (Fig. 10b), the right-lateral shear across the fault is larger, $\sim 30 \mathrm{~mm} / \mathrm{yr}$. It implies that the other active structures with right-lateral motion between these two stations may accommodate the right-lateral shear.

Based on the results of geodetic re-triangulation of 1914-1979 (Chen, 1984), land subsidence prevails on the coastal area of the Pingtung plain. The maximum subsidence rate is $\sim 30 \mathrm{~mm} / \mathrm{yr}$. This significant subsidence may partly result from the prominent groundwater level decrease for aquacultural use. However, in a recent study of the withdrawal of groundwater, Kuo et al. (2001) pointed that long-term observation of the groundwater table in this region either dropped or showed little change over the last decade and suggested that the total subsidence of the southern Pingtung plain may be the result of a combination of region tectonic titling and local over-withdrawal groundwater. These observations are also consistent with the Holocene subsidence patterns estimated from the drilling cores in the Pingtung plain (Lai et al., 2002). However, the average long-term subsidence rate is $\sim 4 \mathrm{~mm} / \mathrm{yr}$. And this 


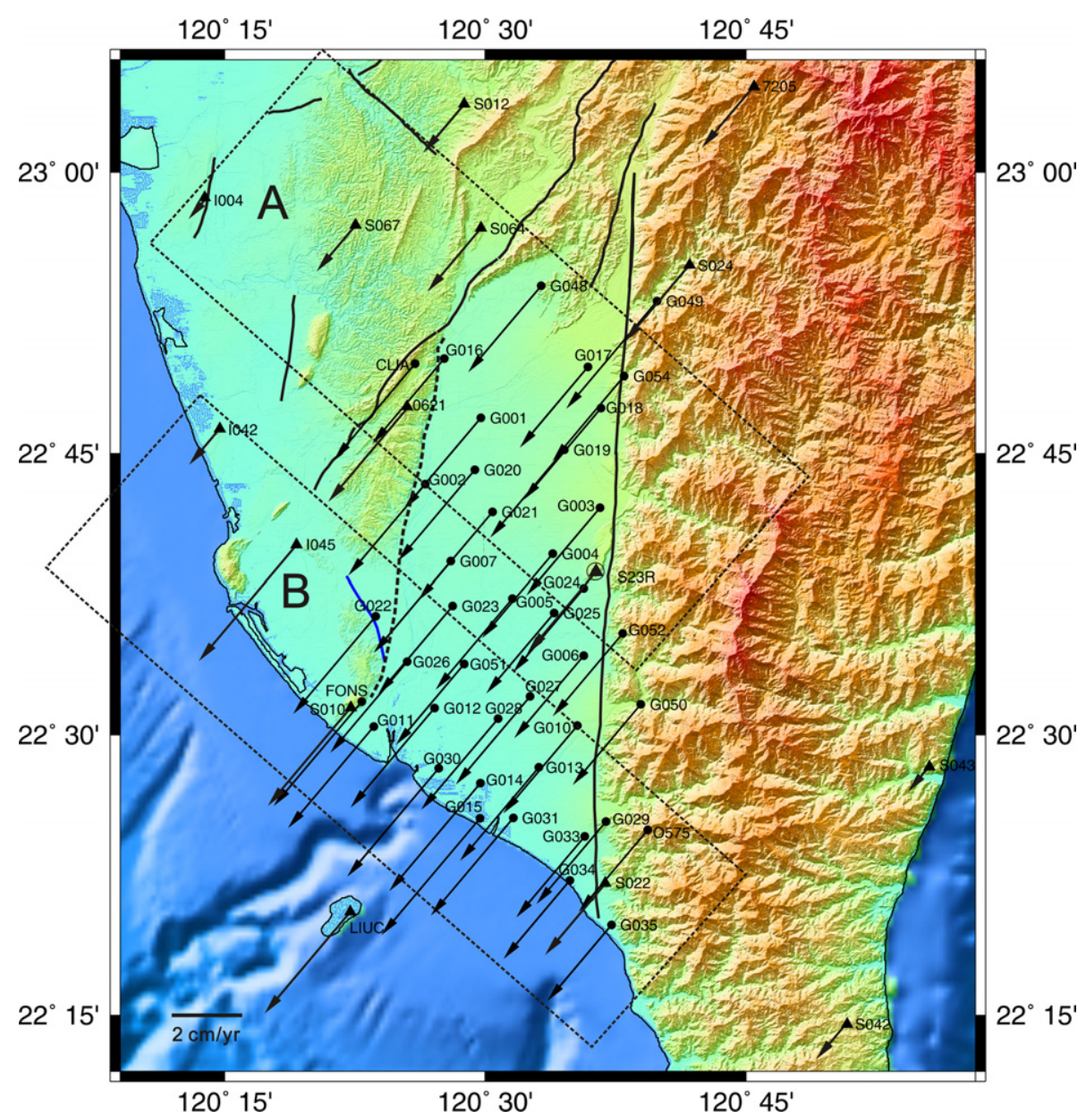

Fig. 9. Plate-motion-normal components of GPS stations on the Pingtung plain relative to Paisha, Penghu (S01R) from 1996 to 1999 . Dotted rectangles are the domains of the profiles (See Fig. 10). Symbols are the same as Fig. 3.

long-term average subsidence rate from Holocene in southern Pingtung plain is much smaller than the observation derived by GPS measurements from 1996 to 1999 (Hu et al., 2006). We infer that this regional subsidence results from both the prominent groundwater level decrease along with rapid subsidence in the coastal region of the Pingtung plain and the transtensional deformation associated with the tectonic extrusion.

\section{Discussion}

Four years of GPS measurements of the PingtunKaohsiung network and the "Taiwan GPS Network" have provided the complete velocity field depiction in SW Taiwan relative to the stable continental shelf. The dense GPS network facilitates the detailed verification of a tectonic model of SW Taiwan. Our results are in general agreement with the previous models of lateral extrusion due to the low lateral confining conditions related to the Manila subduction zone as a free boundary or/and the presence of prominent Peikang High as a rigid indenter (Lu and Malavieille, 1994; Lu et al., 1998; Hu et al., 1997, 2001; Lacombe et al., 1999, 2001; Bos et al., 2003). Based on the rigid blocks models (Angelier et al., 1999; Lacombe et al., 2001), the escaping area comprises four rigid blocks moving toward the SW along major discontinuities with both the lateral and reverse shear. These discontinuities comprise the right-lateral reverse motion of the Deformation Front, right-lateral reverse motion of the Chishan Fault, left-lateral reverse motion of the Kaoping Fault and left-lateral reverse motion of the Chaochou Fault. Within the regional scale, Bos et al. (2003) estimated the velocity gradient field and fault slip rate of the major discontinuities by using the inversion method on the basis of 141 GPS data in the Taiwan area (Yu et al., 1997). They found the right-lateral thrust motion of $\sim 14 \mathrm{~mm} / \mathrm{yr}$ in a $\mathrm{N} 54^{\circ} \mathrm{W}$ direction along the Deformation Front and leftlateral normal motion of $6-13 \mathrm{~mm} / \mathrm{yr}$ in a direction of $\mathrm{N} 110^{\circ}-\mathrm{N} 130^{\circ} \mathrm{E}$ along the Chaochou-Chishan Fault. These predictions suggest the left-lateral motion or leftlateral motion along the Chaochou Fault; however, our results clearly show the insignificant motion along the Chaochou Fault on the basis of both across-strike and along-strike components of GPS data. The disagreement of observation is due to the data density of different GPS networks. The previous GPS data (Yu et al., 1997) are not sufficient to determine the fault slip of the Chaochou Fault if we only consider the difference in direction and 

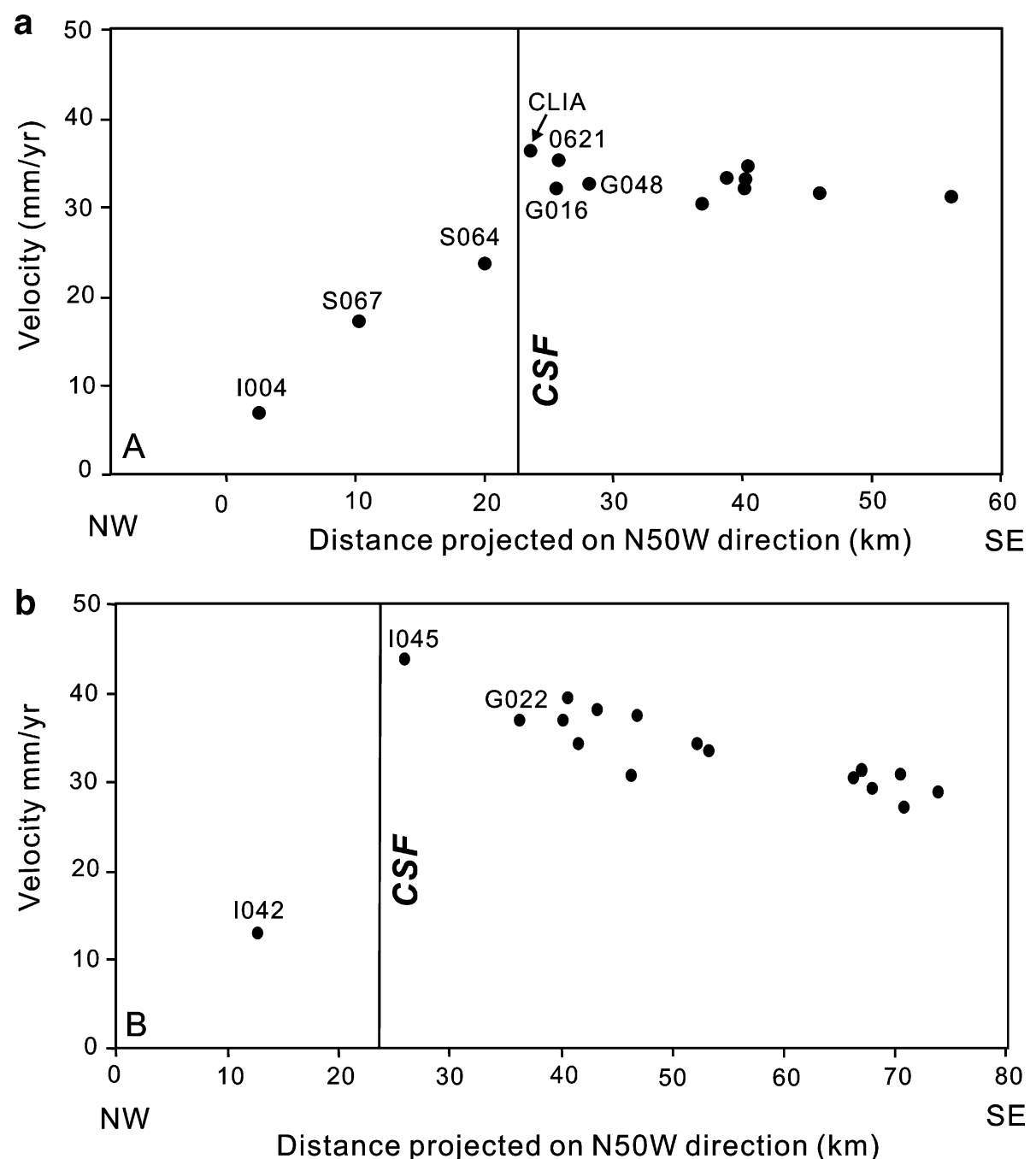

Fig. 10. Plate-motion-normal components of station velocities along two profiles of the study area. CSF, Chishan Fault. Domains of profiles A and B shown in Fig. 9.

magnitude of motion between station S043 and S23R across the whole Slate Belt. We imply that the left-lateral normal motion should accommodate in the Slate Belt. Fisher et al. (2002) pointed out that the southern Backbone Range records extension perpendicular to the mountain belt, and oblique strain axes in the eastern Backbone Range are consistent with left-lateral shear.

One question needs to be addressed clearly about the time and scale of the lateral extrusion in SW Taiwan. Based upon analogue modeling (Lu et al., 1998), predicted the lateral extrusion is mainly produced by Peikang High and could result in a large left-lateral transfer zone around the shelf break of the Chinese continental margin. Lacombe et al. (2001) proposed a different model and suggested that the lateral extrusion is acting on the southern tip of the collision belt, probably south of the Chishan Transfer Fault Zone (CTFZ, for detail see Deffontaines et al., 1997). However, geological observations in SW Taiwan do not show clear evidence of lateral extrusion in the strata of Quaternary formation (Lacombe et al., 1999). This implies that the lateral extrusion process must have developed recently and compatible with the young and ongoing collision in southern Taiwan. They also pointed out the escaping blocks move southwestward to offshore area based on the similar trend of velocity vectors of LIUC, S010, G011, G030 and G015 (Fig. 3). However, the marine morphology and seismic profiles offshore in SW Taiwan also provides no conclusive evidence for tectonic escape (Liu et al., 1997). Indeed, the most recent GPS measurements indicate the velocity field in SW Taiwan (Yu et al., 1997) and in our study area seems to have a systematic trend of increasing southwestward components as a prominent phenomenon of lateral extrusion in SW Taiwan. On the basis of the inversion of BATS (Broadband Array in Taiwan for Seismology) data, Kao and Jian (2001) suggested that the lateral extrusion is probably only a secondary feature in the tectonic processes of Taiwan by two shallow events occurring in SW Taiwan. It is worthy of notice that one strike-slip event at a depth of $24 \mathrm{~km}$ with $P$-axis in the NE-SE direction is a significant indicator that significant shear motion of at least crustal scale exists. Yeh et al. (1991) also pointed out the 
right-lateral motion along NE-trending structures, especially along the frontal thrust zone and the Chishan Fault zone, but the focal depths are not precisely constrained. The significance of counter-clockwise of station velocities is greatly different to those located within the inner part of mountain belt. These observations imply that in the case of SW Taiwan the velocity vectors may reflect the movement of the sedimentary cover and are at least partially decoupled from the deeper crust.

\section{Conclusions}

In summary, the dense GPS network in the Pingtung area shows detailed kinematic behavior of lateral extrusion of the transition zone between collision mountain belt and accretionary prisms of the subduction zone. The distinctive counter-clockwise rotation of the velocity vectors across the Kaohsiung-Pingtung area of SW Taiwan can probably be best explained as a result of the lateral extrusion. Our results clearly demonstrate the transtensional deformation and the along-strike variation of southward increase of extensional deformation in the whole area of southwest Taiwan. The Pingtung plain characterizes the rapid subsidence basin between the Central Range and Western Foothills. The right-lateral and left-lateral structures facilitate the southwestward extrusion and the deformation of the Western Foothills indicates $\mathrm{N}-\mathrm{S}$ stretching and $\mathrm{E}-\mathrm{W}$ shortening. Moreover, GPS vectors indicate that the Chishan Fault is dominated by right-lateral motion with a fault slip rate $\sim 7 \mathrm{~mm} / \mathrm{yr}$ in the $\mathrm{N} 50^{\circ} \mathrm{W}$ direction. The Kaoping Fault bounded on the west side of the Pingtung plain is dominated by left-lateral motion with a $\sim 4-8 \mathrm{~mm} / \mathrm{yr}$ in the $\mathrm{N}-\mathrm{S}$ direction. It is noteworthy that the significant right-lateral component of motion of $\sim 24-30 \mathrm{~mm} / \mathrm{yr}$ should be accommodated on the active structures west of the Chishan Fault between the coast and the deformation front. The right-lateral and left-lateral structures facilitate the southwestward extrusion. The Chaochou Fault is the major fault in the studied area and is considered as the thrust fault with left-lateral movement. Based on our studies, the velocity gradients of the GPS stations across the Chaochou Fault are not significant. This implies that the Chaochou Fault is locked and the mechanical coupling along the fault plane should be very strong. The maximum subsidence rate is about $\sim 30 \mathrm{~mm} / \mathrm{yr}$ near the costal area of southeastern part of Pingtung plain. We infer this regional subsidence maybe due to both the prominent groundwater level decrease with rapid subsidence in the coastal of Pingtung plain as well as the transtensional deformation associated with the tectonic extrusion.

\section{Acknowledgements}

We benefited from fruitful discussions with Jacques Angelier, Chia-Yu Lu, Hao-Tsu Chu, Jian-Cheng Lee, Meng-Long Hsieh, Erwan Pathier and Benoit Deffontaines.
This research was supported by National Science Council of Taiwan grant (NSC93-2116-M-002-008, 94-2119M-002-008) and the Central Geological Survey of the MOEA. Some figures were made using the GMT software written by Paul Wessel and Walter H.F. Smith (1998).

\section{References}

Angelier, J., 1986. Preface. Geodynamics of the Eurasia-Philippine Sea plate boundary. Tectonophysics $125, \mathrm{IX}-\mathrm{X}$.

Angelier, J., Yu, S.-B., Lee, J.-C., Hu, J.-C., Chu, H.-T. 1999. Active deformation of Taiwan collision zone: discontinuities in GPS displacement field. In: Workshop International Conference and 4th Sino-French Symposium on Active Subduction and Collision in Southeast Asia, Memoires Geosciences-Montpellier, $\mathrm{N}^{\circ} 14$, Program and extended abstracts, pp. 287-290.

Angelier, J., Chu, H.-T., Lee, J.-C., Hu, J.-C., 2000. Active faulting and earthquake risk: the Chihshang fault case, Taiwan. Journal of Geodynamics 29, 151-185.

Angelier, J., Lee, J.-C., Chu, H.-T., Hu, J.-C., Lu, C.-Y., Chan, Y.-C., Lin, T.-J., Font, Y., Deffontaines, B., Tsai, Y.-B., 2001. Le Séisme de Chichi (1999) et sa place dans l'orègene de Taiwan. Comptes Rendus de l'Académie des Sciences Paris, Sciences de la Terre et des Planètes 333, $5-21$.

Bonilla, M.G. A review of recently active fault in Taiwan, USGS open-file report 75-41, 1975, pp. 1-55.

Bonilla, M.G., 1977. Summary of Quaternary faulting and elevation changes in Taiwan. Geological Society of China Memoir 2, 43-56.

Bos, A.G., Spakman, W., Nyst, M.C.J., 2003. Surface deformation and tectonic setting of Taiwan inferred from a GPS velocity field. Journal of Geophysical Research 108 (B10), 2458. doi:10.1029/ 2002JB002336.

Byrne, T., Crespi, J. 1997. Kinematics of the Taiwan arc-continent collision and implications for orogenic process, In: International Conference and Sino-American Symposium on Tectonics of East Asia, Taipei, Taiwan, p. 38.

Chai, B.H.T., 1972. Structure and tectonic evolution of Taiwan. American Journal of Science 272, 389-422.

Chan, Y.-C., Lu, C.-Y., Lee, J.-C. 2000. Orogen-parallel shearing in ongoing mountain building: a case study form the southeastern central range of Taiwan, EOS, Transactions American Geophysical Union, Fall Meeting Abstract, 81 (48).

Chen, H-F., 1984. Crustal uplift and subsidence in Taiwan: an account based on retriangulation results, Special Publication of the Central Geological Survey 3, 127-140 (in Chinese).

Chen, Y.-G., Liu, T.-K., 2000. Holocene uplift and subsidence along an active tectonic margin southwestern Taiwan. Quaternary Science Reviews 19, 923-930.

Chiang, C.-S., Yu, H.-S., Chou, Y.-W., 2004. Characteristics of the wedgetop depozone of the southern Taiwan foreland basin system. Basin Research 16, 65-78. doi:10.111/j.1365-2117.2003.00222.x.

Dadson, S.J., Hovius, N., Chen, H., Dade, W.B., Hsieh, M.-L., Willett, S.D., Hu, J.-C., Horng, M.-J., Chen, M.-C., Stark, C.P., Lague, D., Lin, J.-C., 2003. Links between erosion, runoff variability, and seismicity in the Taiwan orogen. Nature 426, 648-651.

Deffontaines, B., Lacombe, O., Angelier, J., Mouthereau, F., Lee, C.-T., Deramond, J., Lee, J.-F., Yu, M.-S., Liu, P.-M., 1997. Quaternary transfer faulting in Taiwan foothills: evidence from a multisource approach. Tectonophysics 274, 61-82.

Dixon, T.H., 1991. An introduction to the global positioning system and some geological applications. Reviews of Geophysics 29, 249 276.

Fisher, D.M., Lu, C.-Y., Chu, H.-T. 2002. Taiwan Slate Belt: insights into the ductile interior of an arc-continent collision. In: Byrne, T.B., Liu, C.-S. (Eds.), Geology and Geophysics of an Arc-Conti- 
nent Collision, Taiwan. The Geological Society of America Special Paper 358, pp. 93-106.

Hickman, J.B., Wiltschko, D.V., Hung J.-H., Fang, P., Bock, Y. 2002. Structure and evolution of the active fold-and-thrust belt of southwestern Taiwan form Global Positioning System analysis. In: Byrne, T.B., Liu, C.-S., (Eds), Geology and Geophysics of an Arc-Continent Collision, Taiwan. The Geological Society of America Special Paper 358, pp. $93-106$.

Ho, C.-S., 1986. A synthesis of the geological evolution of Taiwan. Tectonophysics $125,1-16$.

Hovius, N., Stark, C.P., Chu, H.-T., Lin, J.-C., 2000. Supply and removal of sediment in a landslide-dominated mountain belt: Central Range, Taiwan. The Journal of Geology 108, 73-89.

Hsu, T.-L., Chang, H.-C., 1979. Quaternary faulting in Taiwan. Geological Society of China Memoir 3, 155-165.

Hu, J.-C., Angelier, J., 1996. Modelling of stress-deformation relationship in a collision belt. Taiwan. Terrestrial, Atmospheric and Oceanic Sciences 7 (4), 447-465.

Hu, J.-C., Angelier, J., Lee, J.-C., Chu, H.-T., Byrne, D., 1996. Kinematics of convergence, deformation and stress distribution in the Taiwan collision area: 2-D finite-element numerical modelling. Tectonophysics 255, 243-268.

Hu, J.-C., Angelier, J., Yu, S.-B., 1997. An interpretation of the active deformation of southern Taiwan based on numerical simulation and GPS studies. Tectonophysics 274, 145-169.

Hu, J.-C., Yu, S.-B., Angelier, J., Chu, H.-T., 2001. Active deformation of Taiwan from GPS measurements and numerical simulations. Journal of Geophysical Research 106, 2265-2280.

Hu, J.-C., Yu, S.-B., Chu, H.-T, Angelier, J. 2002. Transition tectonics of northern Taiwan induced by convergence and trench retreat. In: Byrne, T.B., Liu, C.-S., (Eds), Geology and Geophysics of an Arc-Continent Collision, Taiwan. The Geological Society of America Special Paper 358 , pp. $147-160$

Hu, J.-C., Chu, H.-T., Hou, C.-S., Chen, R.-F., Lai, T.-H., Nien, P.-F., 2006. The contribution to tectonic subsidence by groundwater abstraction in the Pingtung area, southwestern Taiwan as determined by GPS measurements. Quaternary International 147, 62-69.

Hugentobler U., Schaer S., Fridez P., 2001. Bernese GPS software, Version 4.2. Astronomical Institute, University of Berne, 515 pp.

Kao, H., Jian, P.-R., 2001. Seismogenic patterns in the Taiwan region: insights from source parameter inversion of BATS data. Tectonophysics 333, 179-198.

Kuo C.-H., Chan Y.-C., Wang C.-H., 2001. Subsidence: over withdrawal groundwater, tectonic or both? EOS Transactions American Geophysical Union, Fall Meeting, Abstract 82 (47) (Suppl.), F479.

Lacombe, O., Mouthereau, F., Deffontaines, B., Angelier, J., Chu, H.-T. Lee, C.-T., 1999. Geometry and Quaternary kinematics of fold-andthrust units of southwestern Taiwan. Tectonics 18, 1198-1223.

Lacombe, O., Mouthereau, F., Angelier, J., Deffontaines, B., 2001. Structural, geodetic and seismological evidence for tectonic escape in SW Taiwan. Tectonophysics 333, 323-345.

Lai, T.-H., Hsieh, M.-L., Liew, P.-M., Chen, Y.-G. 2002. Holocene rock uplift and subsidence in the coastal area of Taiwan. EOS, Transactions American Geophysical Union, Fall Meeting Abstract, 83(47), F1280.

Li, Y.-H., 1976. Denudation of Taiwan island since the Pliocene epoch. Geology 4, 105-107.

Liew, P.-M., Hsieh, M.-L., Lai, C.-K., 1990. Tectonic significance of holocene marine terraces in the coastal range, eastern Taiwan. Tectonophysics $183,121-127$.

Lin, A.T., Watts, A.B., 2002. Origin of the west Taiwan basin by orogenic loading and flexure of a rifted continental margin. Journal of Geophysical Research 107, 2185-2203.

Lin, C.-W., Chang, H.-C., Lu, S.-T., Shih, T.-S., Huang, W.-J., 2000. An introduction of the active faults of Taiwan. Special Publication of the Central Geological Survey 13, $122 \mathrm{pp}$.

Liu, C.-C., Yu, S.-B., 1990. Vertical crustal movements in eastern Taiwan and their tectonic implications. Tectonophysics 183, 111-119.

Liu, C.S., Huang, I.L., Tseng, L.S., 1997. Structural features of southwestern Taiwan. Marine Geology 137, 305-319.
Liu, T.-K., Hsieh, S., Chen, Y.-G., Chen, W.-S., 2001. Thermo-kinematic evolution of the Taiwan oblique-collision mountain belt as revealed by zircon fission track dating. Earth and Planetary Science Letters 186, $45-56$.

Lu, C.-Y., Malavieille, J., 1994. Oblique convergence, indentation and rotation tectonics in the Taiwan mountain belt: insights from experimental modeling. Earth and Planetary Science Letters 121, 477-494.

Lu, C.-Y., Jeng, F.-S., Chang, K.-J., Jian, W.-T., 1998. Impact of basement high on the structure and kinematics of western Taiwan thrust wedge: insights from sandbox models. Terrestrial, Atmospheric and Oceanic Sciences 9 (3), 533-550.

Lundberg, N., Reed, D.L., Liu, C.-S., Lieske, J., 1997. Forearc-basin closure and arc accretion in submarine suture zone south of Taiwan. Tectonophysics 274, 5-23.

Malavieille, J., Lallemand, S.E., Dominquez, S., Deschamps, A., Lu, C.-Y., Liu, C.-S., Schnürle, P., 2002. Arc-continent collision in Taiwan: new marine observations and tectonic evolution. In: Byrne, T.B., Liu, C.-S., (Eds), Geology and Geophysics of an Arc-Continent Collision, Taiwan. The Geological Society of America Special Paper 358, pp. 187-211.

Molnar, P., Tapponnier, P., 1978. Active tectonics of Tibet. Journal of Geophysical Research 83, 5361-5375.

Mouthereau, F., Deffontaines, B., Lacombe, O., Angelier, J., 2002. Variation along the strike of the Taiwan thrust belt: basement control on structural style, wedge geometry, and kinematics. In: Byrne, T.B., Liu, C.-S. (Eds.), Geology and Geophysics of an Arc-Continent Collision, Taiwan. The Geological Society of America Special Paper 358, pp. 31-54.

Pirazzoli, P.A., Arnold, M., Giresse, P., Hsieh, M.-L., Liew, P.-M., 1993. Marine deposits of late glacial times exposed by tectonic uplift on the east coast of Taiwan. Marine Geology 110, 1-6.

Ratschbacher, L., Frisch, W., Linzer, H.-G., Merle, O., 1991. Lateral extrusion in the eastern Alps, part 2: structural analysis. Tectonics 10 (2), 257-271.

Segall, P., Davis, J.L., 1997. GPS applications for geodynamics and earthquake studies. Annual Reviews of Earth Planetary Sciences 25, 301336.

Seno, T., Stein, S., Gripp, A.E., 1993. A model for the motion of the Philippine Sea plate consistent with NUVEL-1 and geological data. Journal of Geophysical Research 98, 17941-17948.

Shyu, J.B.H., 1999. The sedimentary environment of southern Pingdong plain since the last glacial, Master Thesis, National Taiwan University, Taipei, pp. 212.

Shyu, J.B.H., Sieh, K., Chen, Y.-G., Liu, C.-S., 2005. Neotectonic architecture of Taiwan and its implications for future large earthquakes. Journal of Geophysical Research 110, B08402. doi:10.1029/2004JB003251.

Suppe, J., 1984. Kinematics of arc-continent collision, flipping of subduction and back-arc spreading near Taiwan. Geological Society of China Memoir 6, 21-33.

Tapponnier, P., Peltzer, A., Le Dain, Y., Armijo, R., Cobbld, P., 1983. Propagation extrusion tectonics in Asia: new insights from simple experiments with plasticine. Geology 10, 611-616.

Teng, L.S., 1990. Geotectonic evolution of late Cenozoic arc-continent collision in Taiwan. Tectonophysics 183, 57-76.

Teng, L.S., 1996. Extensional collapse of the northern Taiwan mountain belt. Geology 10, 949-952.

Tsai, Y.-B., 1986. Seismotectonics of Taiwan. Tectonophysics 125, 17-37.

Vita-Finzi, C., 2000. Deformation and seismicity of Taiwan. Proceedings of the National Academy of Sciences 97, 11176-11180.

Wang, C.-H., Burnett, W.C., 1990. Holocene mean uplift rates across an active plate collision boundary in Taiwan. Science 248, 204-206.

Wessel, P., Smith, W.H.F., 1998. New, improved version of the generic mapping tools released. EOS Transactions American Geophysical Union 79, 579

Yeh, Y.-H., Barrier, E.C.-H., Lin, C.-H., Angelier, J., 1991. Stress tensor analysis in the Taiwan area from focal mechanisms of earthquakes. Tectonophysics 200, 267-280.

Yu, S.-B., Chen, H.-Y., 1994. Global positioning system measurements of crustal deformation in the Taiwan arc-continent collision zone. Terrestrial, Atmospheric and Oceanic Sciences 5, 477-498. 
Yu, S.-B., Chen, H.-Y., Kuo, L.-C., 1997. Velocity field of GPS stations in the Taiwan area. Tectonophysics 274, 41-59.

Yu, S.-B., Kuo, L.-C., Punongbayan, R.S., Ramos, E.G., 1999. GPS observation of crustal deformation in the Taiwan-Luzon region. Geophysical Research Letters 26, 923-926.
Yu, S.-B., Kuo, L.-C., 2001. Present-day crustal motion along the longitudinal valley fault, eastern Taiwan. Tectonophysics 333, 199-217.

Zang, S.-X., Chen, Q.-Y., Ning, J.-Y., Shen, Z.-K., Liu, Y.-G., 2002. Motion of the Philippine sea plate consistent with the NUVEL-1A model. Geophysical Journal International 150, 809-819. 